\title{
Study on Historical Evolution and Contemporary Revelation of Mao Zedong Thought and Ideologization
}

\author{
Ying Wang \\ Jilin Agricultural University, Changchun 130118, China
}

Keywords: Mao Zedong Thought, Ideologization, Ideology

\begin{abstract}
Chinese reform and opening up has achieved remarkable achievements and our country has undergone tremendous changes. Profound economic and social changes objectively require the further enrichment and development of the country's mainstream ideology. Mainstream ideology is the guide for social action. Ideology is made up of a series of ideas. These ideas not only guide social behavior, but also can be transformed into political, economic and cultural systems. Through the ideological research of Mao Zedong Thought, we can consolidate the fruits of reform and opening up, and improve the socialism system with Chinese characteristics. This paper introduces the concept of ideology of Mao Zedong Thought, studies the historical environment and conditions of Mao Zedong Thought, and explores its ideological process of mainstream consciousness. We also analyze the important enlightenment of Mao Zedong Thought on the construction and development of contemporary Chinese ideology.
\end{abstract}

\section{Introduction}

In recent years, scholars have studied several aspects of Mao Zedong Thought, but the ideological study of Mao Zedong Thought is not common. Mao Zedong Thought is an ideology, and there are many reasons for its formation. This article regards Mao Zedong Thought as an ideology. The most important role of ideology is the political role. Ideology is a political theory, which can guide the political, economic and cultural development in a certain historical conditions.

Mao Zedong and his ideological research are gradually academic, and the research methods and research areas are gradually diversified. The study of Mao Zedong is not just a matter for politicians and thinkers. The understanding of Mao Zedong and his thoughts is not only directly related to the understanding of Chinese history in this century, but also related to the understanding of the Chinese Communist Party. Therefore, this article demonstrates the formation of Mao Zedong Thought and its ideological process [1 3].

\section{Basic concept and theory}

\subsection{Basic concept}

In the theory of Mao Zedong Thought ideologization, Mao Zedong Thought is not only a theory of guiding the Chinese revolution, but also an ideological and theoretical system. It can specify China's future development path and the country's basic construction. In the meantime, it demonstrates the legitimacy of the proletarian regime, and puts its ideological content into political practice, thereby evolving into a political system [4]. Therefore, in the process of ideologization, Mao Zedong Thought was identified as the guiding ideology of the Chinese Communist Party, and it is the mainstream ideology of this country.

\subsection{Theoretical basis}

The theoretical basis of Mao Zedong Thought ideologization has two parts: the theory of Marx's ideology and the theory of Lenin's ideology.

In the theory of Marx's ideology, ideology is a comprehensive and general concept. It includes the various forms of consciousness, such as idea, notion, consciousness, law, morality, religion and metaphysics. Therefore, ideology is the shadow of human activity in a sense. In the class society, 
ideology manifests itself as the thought of the ruling class in essence. The consciousness of the ruling class is dominant in every period. The ruling class not only occupies the material power, but also dominates the spiritual power of society.

In the theory of Lenin's ideology, Lenin inherits the Marxist materialist thought, and he believes that human consciousness is a reflection of the material world and people's social life in the brain. Moreover, he believes that the social relationship of consciousness is the superstructure of the social relationship of material [5]. The social relationship of material is an objective trend independent of man's will. In Lenin's view, consciousness is indeed a reflection of the material world and people's social relations, but the two are not identical. Therefore, we cannot ignore the function and effect of consciousness. The ideology of mankind is developed with the development of social productive forces.

\section{Historical evolution of Mao Zedong Thought ideologization}

The historical evolution of Mao Zedong Thought ideologization has four parts, including germination period, exploration period, formation period and development period.

\subsection{Germination period (before 1935)}

In March 1927, Mao Zedong published "Hunan peasant movement inspection report". In his paper, he emphasized the importance of the peasant problem. In the meantime, he expected that a lot of farmers would participate in the revolution from central, southern and northern provinces of China, and the revolution enthusiasm of them was very high. In his opinion, whether the revolution is finished in the peasant movement camp is the key point of the revolution. The process of the peasant movement has three parts, including peasant association, peasant revolution and united front. Although the peasant movement was under the banner of the Kuomintang, the real peasant revolution needed to be led by the Communist Party. In Mao's view, the Chinese revolution has to rely on peasant. Otherwise, it cannot succeed in the period [6 7].

Mao Zedong is the early leader of the Chinese Communist Party and he has a strong "revolutionary" complex. He used the words "revolution" and "counter-revolution" in the article "Analysis of all classes in Chinese society". The term "revolution" is interpreted as "destroying the old decadent social system and establishing a new progressive social system". Chalmers Johnson, a well-known American scholar of the revolution research, said that the "Chinese revolution" of $19^{\text {th }}$ and $20^{\text {th }}$ century is the largest and most complex "revolutionary sample" in the history.

\subsection{Exploration period (1935-1937)}

In Mao's view, the Chinese Communist Party's army is not the kind of purely revolutionary tool in history. In a sense, the army is a tool for the implementation of political tasks. They are responsible for carrying out major tasks such as mass propaganda, mass organization, mass arming and mass assistance. The Red Army is different from other troops in history. The army must accept the leadership of the party, and it is the tool for party to complete the political task. This is the "party command gun" principle.

In the general concept, the matter of masses is not a big thing, and only the matter of government or officials is a major event, which is related to the traditional Chinese concept. Therefore, the party has formed a deep-rooted bureaucratic style. However, Mao's life is a constant struggle with bureaucracy. Therefore, mass lines become a magic weapon of Communist Party in the revolutionary period. The Communist Party is the best example of mass work, they concern about the lives and suffering of the masses.

\subsection{Formation period (1937-1945)}

After the development of the agrarian revolution, the Chinese Communist Party not only developed a red army, but also enhanced their ability based on the conflict with the Kuomintang. In this procedure, the Communist Party is becoming more and more mature. After the war of resistance against Japan and the Great Revolution, the Chinese Communist Party finally gained its legal status, and the Red Army was also incorporated into the national revolutionary army. Therefore, the Red Army's weapon, 
equipment and logistics support has a corresponding protection. This situation has continued to the "Southern Anhui Incident", thus leading to a collapse of cooperation [8].

During this period, the Chinese Communist Party established a border regime in northern Shaanxi, developed and strengthened its own army, and opened up a number of enemy-based anti-Japanese base areas. During this period, it is noteworthy that Mao Zedong's theory is maturing, thus forming Mao Zedong Thought. It has the basic characteristics of ideology, and it gradually affects the Chinese values and cultural concepts.

\subsection{Development period (1945-1981)}

In 1940, "New Democracy" was a sign of Mao Zedong Thought. Until 1949, Mao Zedong discussed and analyzed all aspects of Chinese society. With the establishment of the new China, the Chinese Communist Party become the ruling party, and it also is the only ruling party. After the founding of the PRC, Mao Zedong continued to enrich and develop his theoretical system, especially the new democratic and socialist construction theory.

\section{Contemporary revelation of Mao Zedong Thought ideologization}

Mao Zedong Thought is the crystallization of the wisdom of the first generation of the Chinese Communist Party, and is a very valuable asset for the Chinese Communist Party and the Chinese people. The ideology of Mao Zedong Thought has provided some enlightenment to the construction and development of contemporary China.

\subsection{Relationship analysis}

The relationship between the theory of socialism with Chinese characteristics and Mao Zedong Thought is reflected in two aspects: inheritance and expansibility.

(1) Inheritance: In contemporary China, Mao Zedong Thought, Deng Xiaoping Theory, important thought of the "Three Represents" and scientific development concept and "China Dream" are closely linked. These theories are the result of ideology based on leading ideology of the Chinese Communist Party, and they are the result of the continuous integration of Marxism with China's actual situation. In the meantime, these results can be divided into different content based on their theme, including new democratic theory, socialist construction theory and socialism with Chinese characteristics.

(2) Expansibility: Mao Zedong Thought is a creative theoretical system, and its main representative is Mao Zedong. In the Chinese revolution and construction, the basic principles of Marxism and Leninism are combined with China's reality, thereby producing the Mao Zedong Thought. It is not a rigid theory, but a living theoretical system. It needs the driving force to constantly enrich and perfect this theory in different historical conditions.

\subsection{Ideological leadership}

The Communist Party must firmly grasp the ideological leadership. From 1989 to 1995, socialism suffered a great setback on a global scale, and the international situation and domestic political turmoil forced people to turn their attention to ideological issues. Through the successful experience and the lessons of failure, the Chinese Communist Party has improved its own ideology theory. Moreover, they summed up an important experience, that is, the Communist Party must firmly grasp the ideological leadership. In the current complex and changing international environment, blindly ideologies and differences are harmful. In a sense, there are many forms of competition or struggle between the two main ideologies of socialism and capitalism.

\subsection{The establishment of mainstream ideology}

In the increasingly complex contemporary world, it is particularly important to establish an ideology, thereby improving human civilization and progress. Similarly, the establishment of national concepts can bring the hope and motivation to the country and the nation. It can not only shape the citizenship, but also shape a country's culture. In China, there is no doubt that the Chinese Communist Party has the leadership of leading ideology. However, ideology is the "national rationality" and "national consciousness" of nation and country. Under the contemporary conditions, the Chinese Communist Party should timely, accurately and effectively transform the Party's ideological theory 
into "national rationality" or "national consciousness", thereby obtaining greater appeal, influence and mobilization.

\section{Conclusion}

This paper studies the ideological process of Mao Zedong Thought, analyzes the historical environment and conditions of Mao Zedong Thought, and explores its ideological process of mainstream consciousness. In the meantime, we describe the basic theory of Mao Zedong thought ideologization, and analyze the process of Mao Zedong Thought. The process of ideology is, in a sense, a process of institutionalization of ideology. Through the ideological study of Mao Zedong Thought, we can enrich and develop the theoretical system of socialism with Chinese characteristics and enhance the theoretical creativity of the Chinese Communist Party. In the meantime, we can improve the core value system of socialism with Chinese characteristics, enhance the theoretical self-confidence, and strengthen the national spirit construction. Therefore, we can consolidate the fruits of reform and opening up, improve the socialism system with Chinese characteristics, which has important practical value for the road of socialism with Chinese characteristics

\section{References}

[1]. Gregor, A. J. (2014). Mao Zedong Thought. In Marxism and the Making of China (pp. 141-165). Palgrave Macmillan US.

[2]. Yi-qin, Y. (2010). A Review of the Studies on Mao Zedong's Ethical Thoughts in the Past Sixty Years. Qilu Journal, 1, 012.

[3]. Jian-fei, X. U. (2011). A Study on the Significance of Mao Zedong Thought to the Development of China [J]. Journal of Sichuan University of Science \& Engineering (Social Sciences Edition), 4, 002 .

[4]. Perry, E. J. (2008). Chinese conceptions of "rights": From Mencius to Mao-and now. Perspectives on Politics, 6(01), 37-50.

[5]. Xizhe, W. (2015). Mao Zedong and the Cultural Revolution. On Socialist Democracy and the Chinese Legal System (Armonk, NY: ME Sharpe, 1985), 177-259.

[6]. Jin, S. U. N. (2009). A Study on Research of Mao Zedong's Contributions to Chinese Marxism in Recent Years [J]. Studies on Mao Zedong and Deng Xiaoping Theories, 5, 015.

[7]. YANG, Z. E., \& CHEN, P. (2010). The Promotion of Mao Zedong's thought of Culture and the Flourish of Socialist Culture with Chinese characteristics [J]. Journal of Mianyang Normal University, 1, 032.

[8]. Faqin, L. U. (2009). Mao Tse-tung Thought and Socialism Theoretical System with Chinese Characteristics [J]. Journal of Shenyang University, 1, 012. 